\title{
Evaluation of Yellowing Intensity of Sugar Beet Leaves Infected with Rhizomania by Using a Handheld Chlorophyll Meter
}

\author{
Hirokatsu UCHINO* and Katsuichi KANZAWA*
}

Key words : yellowing intensity, chlorophyll meter, SPAD, rhizomania, sugar beet.

Rhizomania of sugar beets caused by beet necrotic yellow vein virus transmitted by Polymyxa betae $e^{7)}$ has been reported to exhibit various symptoms in leaves ${ }^{2,4,6}$, which have greenish-yellowing, narrow shaped-leaf blades, elongated petioles and an upright posture. It was thought that the yellowing was the most typical symptom of rhizomania and was caused by the decrease of chlorophyll contents in a leaf, similar to nutrient deficient leaves ${ }^{3)}$. It was reported that the disease severity of rhizomania was shown as the yellowing intensity of leaves determined by observation ${ }^{1,11)}$. Evaluation by this method, however, might require more experience of researchers and furthermore, might vary depending on weather conditions.

Therefore, it is necessary to develop a more simple and objective method to evaluate the severity of rhizomania in fields. Depth of leaf green can be measured without damage to the plants with a handheld chlorophyll meter (SPAD-502, Minolta Camera Co., Ltd., Japan) using optical density difference at two wavelengths. The optical density measured by this apparatus is stated as a SPAD value and is proportional to the amount of chlorophyll in a leaf. Consequently, it is suspected that the SPAD value indicates the yellowing intensity of leaves of sugar beets infected with rhizomania.

In order to evaluate the yellowing intensity of sugar beet leaves infected with rhizomania, this paper deals with the distinction between rhizomania, nitrogen deficient and healthy plants with SPAD, and the relation between the SPAD value and the root quality; root yield, sugar content and rhizomania factor.

Comparison of the SPAD value between rhizomania and healthy beets cultivated in various conditions. Sugar beets are affected by rhizomania in nursery beds and/or in fields, because a transplanting system is used for the cultivation of sugar beets in Hokkaido. The SPAD values of mature leaves were measured to compare rhizomania and healthy beets cultivated under 3 conditions; 1 ) cultivation for 4 months in non-infested fields ( $14.4 \mathrm{~m}^{2}$ per plot) after transplanting seedlings grown in nursery beds for 50 days with infested soil or fumigated soil, 2) cultivation for 3 months in pots (49 $\mathrm{cm}$ in diameter) outdoors with infested or steam-sterilized soil and 3) cultivation for 40 days in cups $(7 \mathrm{~cm}$ in diameter) with inoculated or noninoculated quartz sand in greenhouse. The results are shown in Table 1. Yellowing of rhizomania leaves clearly appeared in all 3 conditions. The SPAD values of rhizomania beets was remarkably lower than those of non-infected beets cultivated under the above 3 conditions. All of SPAD values of rhizomania beets were below 30 . The SPAD values differed over 10 between rhizomania and non-infected beets under the same condition. Beet necrotic yellow vein virus was detected in roots infected with rhizomania with ELISA $^{8)}$, but not in non-infected roots in all 3 conditions.

The distribution pattern of SPAD value in a leaf of rhizomania in comparison with nitrogen deficient and healthy plants. It was tested to characterize 1) the SPAD value of mature leaves (3-8 leaf position) and 2) the distribution pattern of the SPAD value in a sugar beet leaves among rhizomania, nitrogen deficient and healthy plants (Fig. 1). The mean value of the mature leaves of rhizomania, nitrogen deficient and healthy plants were 25, 17 and 38, which showed greenish yellowing, extreme yellowing and a normal green color, respectively. The SPAD values varied depending on leaf age in an individual sugar beet. In rhizomania and healthy plants, while the values were lower in young and senescent leaves, the values were higher in mature leaves. Therefore, when the values were plotted in a figure in the order of young, mature and old leaves, the pattern showed a trapezoid shape. On the contrary, in nitrogen deficient leaves, the pattern was different from the trapezoid because the values were gradually decreased from young to old leaves. From the comparison of the SPAD value of both patterns, the SPAD value of leaves infected with rhizomania was characterized by 1) a lower value in comparison with that of healthy leaves, and 2) the trapezoid pattern plotted in a figure as compared to nitrogen deficient leaves which showed a gradually decreasing pattern.

The relation between the SPAD value of leaves and the damage of beet roots. It is reported that the severe damage of rhizomania occurs in fields with 
Table 1. Comparison of SPAD value in leaves between rhizomania and healthy beets cultivated in the field, pot and cup

\begin{tabular}{|c|c|c|c|c|c|c|}
\hline \multirow{2}{*}{$\begin{array}{l}\text { Condition } \\
\text { cultivated }\end{array}$} & \multirow[b]{2}{*}{ Treatment } & \multirow{2}{*}{$\begin{array}{c}\text { No. of plants } \\
\text { detected } \\
\text { BNYVV }\end{array}$} & \multirow{2}{*}{$\begin{array}{c}\text { Fresh } \\
\text { weight } \\
\text { (g/plant) }\end{array}$} & \multicolumn{3}{|c|}{ SPAD value ${ }^{\mathrm{e})}$} \\
\hline & & & & $\begin{array}{l}\text { No. of plants } \\
\text { measured }\end{array}$ & Mean & S.D. \\
\hline \multirow[t]{2}{*}{ Field $^{\mathrm{a})}$} & Bed soil infested & $3 / 3$ & 975 & 42 & 26.7 & 6.2 \\
\hline & Bed soil fumigated & $0 / 3$ & 1546 & 42 & 37.3 & 4.6 \\
\hline \multirow[t]{2}{*}{$\operatorname{Pot}^{\text {b) }}$} & Soil infested & $13 / 14$ & 88 & 14 & 20.6 & 3.0 \\
\hline & Soil steam sterilized & $0 / 14$ & 193 & 14 & 33.2 & 4.7 \\
\hline \multirow[t]{2}{*}{ Cup $^{c)}$} & Quartz sand inoculated & $20 / 20$ & 38 & 20 & 17.4 & 2.9 \\
\hline & Quartz sand no inoculated & $0 / 20$ & 34 & 20 & 30.6 & 4.3 \\
\hline
\end{tabular}

a) Three replicates of seedlings were transplanted in a non-infested field in May after growth in the nursery bed with infested or fumigated soil for 50 days. One plot was $14.4 \mathrm{~m}^{2}$. SPAD value was measured in September.

b) Healthy 60 days old seedlings were transplanted in large pots $(49 \mathrm{~cm}$ in diameter) with infested or steam sterilized soil. SPAD value was measured after growing outdoors for 3 months.

c) A healthy 2 weeks old seedling was transplanted in a plastic cup ( $7 \mathrm{~cm}$ in diameter) with inoculated or non-inoculated quartz sand. Air-dried rootlets containing cystosorii of Polymyxa betae was used as inoculum. They were mixed in quartz sand in the rate of $10 \mathrm{mg} /$ cup. SPAD value was measured after growing in greenhouse (day $25^{\circ} \mathrm{C}$, night $17^{\circ} \mathrm{C}$ ) for 40 days.

d) These were number of plots or plants which were above 0.1 with the absorbance value ( $405 \mathrm{~nm}$ ) of tap root by ELISA. All 10 tap roots were mixed and measured for each plot in the field trial. Every tap roots were measured in the pot and cup trials.

e) SPAD value was measured for every plants (one leaf of mature leaves from each plant). S.D. : Standard deviation.
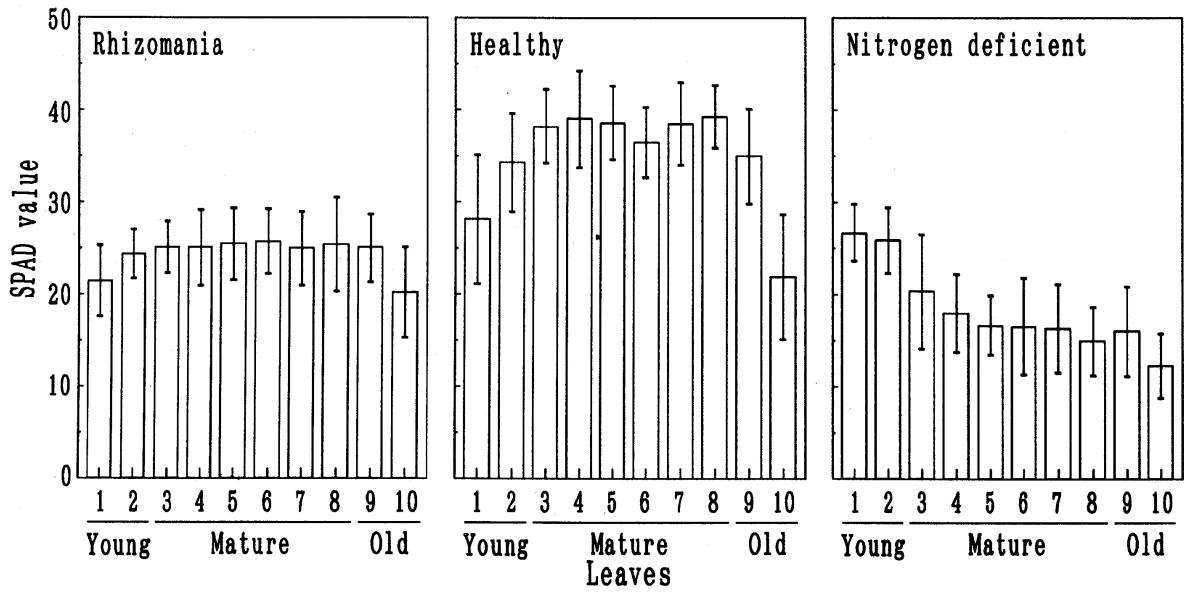

Fig. 1. Comparison of the distribution pattern of SPAD value depending on leaf age among rhizomania, nitrogen deficient and healthy plants. Each value on the figure represents the mean of ten plants with standard deviation. All data for each plant were divided into 10 positions and calculated after measurement because the number of leaves was different each plant measured (16-37 leaves).

higher soil $\mathrm{pH}^{9)}$. In this experiment, 5 fields which were given different amounts of lime (0-12 t/ha) and planted sugar beets for 20 years continuously, were used to study the relation between the SPAD value and root qualities (root yield, sugar content and rhizomania factor). The occurrence of rhizomania and the yellowing intensity of leaves were different in each field. Soil $\mathrm{pH}$ of these fields were $6.29,6.31,6.56,6.73$ and 6.89 , and these SPAD values were 33.0, 31.0, 29.6, 28.4 and 20.3, respectively. The lower SPAD value was measured in the field which had higher soil $\mathrm{pH}$ and distinct yellowing of leaves. Less root yield and less sugar content were obtained in fields with the lower SPAD value of mature leaves. The rhizomania factor, which indicated the damage caused by rhizomania ${ }^{5)}$, exhibited the higher value in fields with the lower SPAD value of mature leaves. It was found that the SPAD value had a positive correlation with sugar yield and had a negative correlation with the rhizomania factor (Fig. 2).

The SPAD value of leaves of rhizomania beets was always lower than that of non-infected beets grown under the same conditions. Yellowing intensity of beet leaves infected with rhizomania could be expressed as the mean SPAD value of mature leaves. Leaf color of sugar beets is influenced by various cultivated conditions and/or sugar beet cultivars. The SPAD values of healthy beets were 32 to 37 when they were planted under the 80 to $240 \mathrm{~kg} /$ ha levels of nitrogen fertilization in ordinary volcanic ash fields. SPAD values of several cultivars were 36 to 40 under the $120 \mathrm{~kg} /$ ha level in the same fields. It was suggested that the SPAD value of healthy leaves of any cultivar was above 30 under 

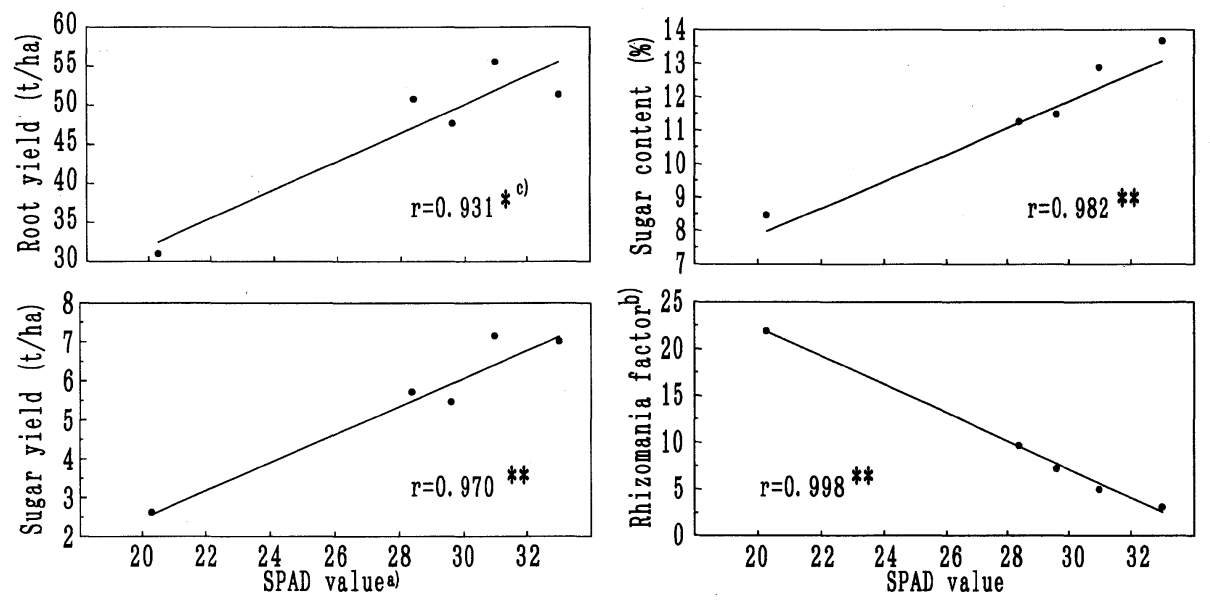

Fig. 2. Relation between SPAD value of leaves and the damage of beet roots. a) SPAD value was measured for every one leaf of mature leaves from 20 plants per field. Beet roots of $15 \mathrm{~m}^{2} /$ field were harvested and analyzed for root yield, sugar content, amount of potassium, sodium and amino nitrogen. b) Rhizomania factor $=\mathrm{K} \times \mathrm{Na} /$ amino N. c) Correlation coefficient ${ }^{*}$; at $5 \%$ level, ${ }^{* *}$; at $1 \%$ level.

ordinary cultural conditions. The SPAD value of rhizomania beets correlated with the yellowing severity determined by observation. The SPAD value of 20 and 30 were proportionate, 75 to 100 and 25 to 50 , of Abe's yellowing severity ${ }^{11}$, respectively.

The yellowing is the typical symptom of rhizomania as similar to nitrogen deficient leaves. The SPAD value of mature leaves of both rhizomania and nitrogen deficient beets were lower than that of healthy beets. Rhizomania beets, however, could be distinguished from nitrogen deficient beets in contrast to the distribution pattern of SPAD values. For nitrogen deficient beets, the color of young leaves becomes an intense green, while mature and old leaves turn to yellow with nitrate depletion ${ }^{10)}$. The yellowing of rhizomania was clearly different from that of nitrogen deficiency.

On account that the yellowing intensity of rhizomania is quantitatively able to be indicated as the SPAD value, we could conclude that the measurement of SPAD value with the handheld chlorophyll meter was helpful to evaluate the yellowing intensity and the damage of sugar beets to rhizomania in the trials for the selection of resistant varieties, the screening of chemicals, etc.

The authors thank Dr. Y. Homma, Hokkaido National Agricultural Experiment Station, for critically reviewing this manuscript. Thanks are also due to Dr. T. Tamada, Hokkaido Central Agricultural Experimental Station, for his kind supply of BNYVV antibody.

\section{Literature cited}

1. Abe, H., Akashi, K. and Tamada, T. (1985). Relation between patterns of occurrence of rhizomania disease of sugar beet and physical and chemical properties of soil in Chitose area. Proc. Sugar Beet Res. Assoc., Japan 27 : 57-64.

2. Abe, H., Mano, Y., Otokozawa, R. and Oogaki, S. (1972).
Survey on the occurrence of rhizomania in the sugar beet in Kitami district. Bull. Sugar Beet Res., Japan, Suppl. 14:1-7.

3. Hayasaka, M., Uchino, H. Imura, E. and Kanzawa, K. (1988). Content of sugar and mineral nutrients of sugar beets, classified by type of rhizomania symptoms. Proc. Japan. Soc. Sugar Beet Technol. 30 : 94-99.

4. Hill, S.A. and Torrance, L. (1989). Rhizomania disease of sugar beet in England. Plant Pathol. 38: 114-122.

5. Kanzawa, K., Uchino, H. and Yamakami, M. (1989). A method for estimating rhizomania damage. Proc. Japan. Soc. Sugar Beet Technol. 31: 87-92.

6. Kanzawa, K. and Ui, T. (1972). A note on rhizomania of sugar beet in Japan. Ann. Phytopathol. Soc. Jpn. 38 : 434-435.

7. Tamada, T. and Baba, T. (1973). Beet necrotic yellow vein virus from rhizomania affected sugar beet in Japan. Ann. Phytopathol. Soc. Jpn. $39: 325$.

8. Tamada, T. and Hagita, T. (1982). Detection of Beet necrotic yellow vein virus (BNYVV) with ELISA. Ann. Phytopathol. Soc. Jpn. 48 : 399-400 (Abstr. in Japanese).

9. Ui, T. (1973). A monographic study of rizomania of sugar beet in Japan. Proc. Sugar Beet Res. Assoc., Japan $15: 233-267$.

10. Ulrich, A. and Hills, F.J. (1969). Sugarbeet nutrient deficiency symptoms-A color atlas and chemical guide. Univ. Calif., Div. Agric. Sci. pp. 10-11.

11. Winner, von C. and Schäufele, W.R. (1977). Orientierende Untersuchungen über den Einfluß der durch Polymyxa betae verursachten Wurzelbärtigkeit auf die Qualität von Zuckerrüben. Zucker 30 : 459-463.

\section{和 文 摘 要}

内野浩克・神沢克一：携帯型葉緑素計を用いたテンサイそう 根病葉の黄化程度の評価

2 波長光学濃度差測定方式の携帯型葉緑素計 SPAD-502 用 いて，テンサイそう根病による黄化葉の黄化程度の評価を試み た。健全個体の SPAD 值を葉位別に図示すると，芯葉及び外葉 
部では低いが，成葉部ではほぼ一定の高い值を示す台形のパタ ーンが描かれた。そう根病個体の SPAD 值は, 健全個体と同様, 台形のパターンを示したが, 同一栽培条件下では健全個体に比 べて常に低い值となった。黄化症状として一般的な窒素欠乏の 個体も SPAD 值は低かったが, 芯葉から外葉に向かって值が漸 減するパターンを示すため, そう根病個体とは区別できた。そう
根病による黄化の激しい戋場では SPAD 值はより低い値とな り, SPAD 值とテンサイ根部の被害との間には相関が認められ た。以上より，そう根病の罹病程度を SPAD 值を用いた黄化程 度として定量的に測定できることが明らかとなった。

(Received September 26, 1994 ; Accepted November 7, 1994) 